\title{
Pengaruh Karakteristik Perusahaan Terhadap Lamanya Penyelesaian Audit (Audit Delay) (Studi Empiris pada Perusahaan Food And Beverage yang Terdaftar Di Bursa Efek Indonesia Periode 2017-2019)
}

\author{
Friska Yuliana*, Riana Rachmawati Dewi, Rosa Nikmatul Fajri \\ Universitas Islam Batik \\ JL. KH. Agus Salim No. 10, Surakarta, Indonesia \\ ${ }^{*}$ Correspondence email: friskay50@gmail.com
}

\begin{abstract}
Abstrak. Penelitian ini bertujuan untuk menguji dan menganlisis pengaruh ukuran perusahan, ukuran KAP, profitabilitas, solvabilitas dan komite audit pada audit delay. Populasi dalam penelitiann ini adalah perusahaan manufaktur food and beverage yang terdaftar di Bursa Efek Indonesia (BEI) tahun 2017-2019. Jenis penelitian ini adalah penelitian kuantitatif. Pengambilan sampel dengan teknik purposive sampling menghasilkan 15 perusahaan manufaktur food and beverage tahun 2017-2019 sesuai kriteria yang ditentukan, sehingga diperoleh 45 data penelitian. Penelitian ini menggunakan analisis regresi linear berganda. Hasil penelitian ini disimpulkan bahwa profitabilitas dan solvabilitas berpengaruh pada audit delay. Sedangkan ukuran perusahaan, ukuran KAP dan komite audit tidak berpengaruh pada audit delay.
\end{abstract}

Kata Kunci: Ukuran Perusahaan; Ukuran KAP; Profitabilitas; Solvabilitas; Komite Audit; Audit Delay.

\begin{abstract}
This study aims to test and analyze the influence of company size, KAP size, profitability, solvency and audit committee on audit delay. The population in this research is a food and beverage manufacturing company listed on the Indonesia Stock Exchange (IDX) in 2017-2019. This type of research is quantitative research. Sampling with purposive sampling technique resulted in 15 food and beverage manufacturing companies in 2017-2019 according to the specified criteria, resulting in 45 research data obtained. This study used multiple linear regression analysis. The results of this study concluded that the profitability and solvency have an effect on audit delay. While the size of the company, size of KAP and audit committee has no effect on audit delay.
\end{abstract}

Keywords: Company Size; KAP Size; Profitability; Solvency; Audit Committee; Audit Delay

\section{PENDAHULUAN}

Perkembangan pasar modal di Indonesia mengalami perkembangan yang cukup signifikan, hal ini terlihat dari jumlah perusahaan go public yang terus meningkat. Semua perusahaan yang terdaftar di Bursa Efek Indonesia memiliki beberapa kewajiban salah satunya adalah mempublikasikan laporan keuangan yang sudah selesai diaudit oleh Akuntan Publik. Sesuai Peraturan Otoritas Jasa Keuangan Nomor 29/POJK.04/2016 menyatakan bahwa perusahaan publik yang tercatat di Bursa Efek Indonesia di haruskan untuk menyampaikan laporan keuangan tahunan beserta dengan laporan auditor independen kepada OJK serta mempublikasikan kepada masyarakat paling lambat pada akhir bulan keempat atau 120 hari sesudah tahun tutup buku. Selain itu, berdasarkan informasi yang dapat diakses melalui website resmi Bursa Efek Indonesia pada tahun 2019 ada 10 emiten yang belum menyampaikan laporan keuangan auditor per 31 Desember 2018 atau belum melakukan pembayaran denda atas keterlambatan penyampaian laporan keuangan. Diantara 10 perusahaan tersebut yaitu PT Tiga Pilar Sejahtera Food Tbk, PT Apexindo Pratama Duta Tbk, PT Borneo Lumbung Energi \& Metal Tbk, PT Bakrieland Development Tbk, dan PT Cakra Mineral Tbk, sehingga PT Bursa Efek Indonesia memberikan hukuman suspensi kepada 10 emiten tersebut. Jika terjadi keterlambatan dalam pelaporan keuangan, maka data yang dihasilkan laporan tersebut akan kehilangan keasliannya. Nilai dari laporan keuangan yang dipengaruhi oleh ketepatan waktu penyusunan laporan audit atas laporan keuangan perusahaan. Respon yang tidak baik akan muncul dari investor pasar modal apabila terjadi keterlambatan informasi, hal ini dikarenakan laporan keuangan auditan terdapat informasi yang sangat penting mengenai kondisi perusahaan didalamnya.

Lamanya waktu auditor dalam menyelesaikan tugas auditnya dapat mempengaruhi ketepatan waktu perusahaan untuk mempublikasikan laporan keuangan kepada OJK dan masyarakat, penyampaian laporan keuangan tidak lepas dari proses audit hingga laporan keuangan dan laporan auditor independen dapat dipublikasikan kepada pihak eksternal (Wardan \& Mushawir, 2017). Periode waktu antara tahun fiskal laporan keuangan dengan tanggal penandatanganan laporan audit independen mengindikasikan tentang lamanya waktu penyelesaian pekerjaan audit yang dilakukan oleh auditor atau yang sering disebut audit delay (Liwe et al., 2018). 
Batas waktu tentang keterlambatan publikasi laporan keuangan yaitu 120 hari atau bulan keempat setelah penutupan buku. Hal ini sesuai dengan keputusan BAPEPAM dan LK No. Kep-431/BL/2012 tentang kewajiban penyampaian laporan tahunan Peraturan Nomor X.K.6 nomer 1 poin a dimana dinyatakan bahwa emiten atau perusahaan publik yang menyatakan pendaftaraanya telah menjadi efektif menyampaikan laporan tahunan kepada Bapepam dan LK paling lama 4 (empat) bulan setelah tahun buku berakhir. Peraturan ini berlaku untuk penyusunan laporan tahunan untuk tahun buku yang berakhir pada atau setelah tanggal 31 Desember 2012 (Candraningtiyas \& Luh, 2017). Penyampaian laporan keuangan yang tertunda bisa disebabkan oleh besarnya ukuran suatu perusahan semakin besar ukuran suatu perusahaan maka waktu yang dibutuhkan untuk mengaudit laporan keuangan akan semakin lama, karena perusahaan yang besar memiliki akun-akun yang bervariasi disertai saldo akun dengan jumlah yang lebih besar dibanding perusahaan dengan ukuran yang lebih kecil, sehingga dibutuhkan waktu yang lebih lama untuk menyelesaikan proses audit yang menyebabkan risiko perusahaan mengalami keterlambatan publikasi laporan keuangan lebih besar (Pangerapan, 2019). Ukuran perusahaan adalah skala dimana skala dimana diklasifikasikannya perusahaan menurut besar kecilnya perusahaan tersebut, besar kecilnya suatu perusahaan dapat dilihat dari jumlah pendapatan, total aset, jumlah karyawan dan total modal (Tantama \& Yanti, 2018). Penelitian Simatupang Laurencius, Putra Wirmie Eka (2018) menyatakan ukuran perusahaan berpengaruh terhadap audit delay karena ukuran besar kecilnya perusahaan dapat menggambarkan aktivitas sebuah perusahaan. Perusahaan-perusahaan berskala besar cenderung menghadapi tekanan eksternal yang lebih tinggi agar segera mengumumkan laporan audit. Berdasarkan hasil penelitian yang dilakukan Firliana, (2015) diketahui bahwa ukuran perusahaan memiliki pengaruh signifikan terhadap terjadinya audit delay.

Selain ukuran perusahaan, menurut (Apriani \& Rahmanto (2017) Ukuran Kantor Akuntan Publik dapat membantu penyelesaian laporan keuangan dengan lebih cepat. Sistem yang digunakan lebih canggih dan akurat karena biasanya didukung dengan kerjasama internasional dengan sumber dana yang besar. Hal yang biasa terjadi adalah Kantor Akuntan Publik besar akan memperoleh insentif yang lebih tinggi untuk menyelesaikan pekerjaan auditnya lebih cepat dibandingkan KAP lainnya. KAP besar juga akan berusaha mempertahankan reputasinya dengan waktu audit yang lebih cepat, diantaranya dapat diukur berdasarkan jumlah karyawan, jumlah klien, serta reputasi. Kantor Akuntan Publik besar memiliki jumlah yang karyawan yang banyak, dapat mengaudit dengan lebih efisien dan efektif, memiliki jadwal yang fleksibel sehingga memungkinkan untuk menyelesaikan audit tepat waktu, serta memiliki dorongan yang lebih kuat untuk menyelesaikan auditnya lebih cepat guna menjaga reputasinya. Hasil penelitian (Putra, 2017) diketahui bahwa KAP berpengaruh terhadap audit delay. Hal lain yang juga dapat mempengaruhi kecepatan laporan keuangan ialah profitabilitas. Perusahaan yang mempunyai tingkat profitabilitas tinggi membutuhkan waktu yang lebih cepat dalam pengauditan laporan keuangan. Hal ini dikarenakan keharusan perusahaan untuk menyampaikan kabar baik secepatnya kepada publik (Apriyana, 2017) hal ini didukung dari hasil penelitian Rosalia, Sukesti, \& Wibowo, (2018) yang menyatakan bahwa profitabilitas memiliki pengaruh terhadap audit delay.

Pembuatan laporan keuangan, faktor lain yang dapat menghambat ialah tingginya proporsi dari hutang akan meningkatkan pula resiko keuangan suatu perusahaan. Oleh karena itu, perusahaan yang memiliki kondisi keuangan yang tidak sehat cenderung dapat melakukan mismanagement dan fraud. Hal ini pada akhirnya memerlukan kecermatan yang lebih dalam dalam pengauditan, sehingga diperlukan kemampuan perusahaan atau solvabilitas dalam membayar semua kewajibannya (baik kewajiban jangka panjang maupun jangka pendek) dari harta perusahaan tersebut. (Hidayat, 2017). Penelitian Tantama \& Yanti (2018) menyatakan solvabilitas berpengaruh terhadap audit delay karena rasio solvabilitas yang tinggi mengakibatkan panjangnya waktu yang dibutuhkan dalam penyelesaian audit. Jumlah hutang yang tinggi yang dimiliki perusahaan akan menyebabkan proses audit yang relatif lebih lama. Hal ini dikarenakan dalam proses pengauditan, auditor perlu kehati-hatian serta kecermatan yang lebih dalam karena menyangkut kelangsungan hidup perusahaan.

Untuk mempercepat kinerja audit maka jumlah komite audit menentukan dan membuat audit delay akan semakin singkat, Komite audit secara resmi diberlakukan di Indonesia sejak Juni 2000, dengan dikeluarkannya Keputusan Direksi Bursa Efek Jakarta No: Ke315/BEJ/06/2000. Dalam keputusan Ketua Bapepam No. Kep29/PM/2004 tentang peraturan Nomor IX.1.5: Pembentukan dan Pedoman Pelaksanaan kerja Komite Audit. Komite audit memiliki tanggung jawab yang sangat besar pada proses pelaporan keuangan. Apabila komite audit memenuhi tanggung jawabnya untuk melakukan pengawasan pada kepatuhan perusahaan terhadap peraturan yang berlaku, kecil kemungkinan suatu perusahaan akan terlambat dalam menyampaikan laporan keuangannya (Mubarok, 2016). Setiap perusahaan diwajibkan untuk membentuk komite audit minimal 3 orang untuk satu perusahaan. Penelitian dari Purnami et al., (2019) menyatakan bahwa komite audit berpengaruh terhadap audit delay. Hal ini dikarenakan agar perusahaan mampu untuk meminimalisir terjadinya keterlambatan dalam pempublikasian pelaporan keuangan ke publik, karena anggota audit yang bekerja disuatu perusahaan dapat menentukan berapa lama audit delay yang akan dihasilkan oleh perusahaan. Tujuan untuk melakukan penelitian ini adalah untuk mengetahui pengaruh 
Karakteristik Perusahaan Terhadap Lamanya Penyelesaian Audit (Audit Delay) (Studi Empiris Pada Perusahaan Food And Beverage Yang Terdaftar Di Bursa Efek Indonesia Periode 2017-2019).

\section{METODE}

Populasi yang digunakan dalam penelitian ini adalah seluruh perusahaan Food and beverage yang terdaftar di Bursa Efek Indonesia (BEI) tahun 2017-2019. Sampel dalam penelitian ini dipilih dengan metode purposive sampling, dengan kriteria sebagai berikut: (1) Perusahaan Food and Beverage yang terdaftar di Bursa Efek Indonesia yang melaporkan annual report selama tiga tahun berturut-turut pada tahun 2017-2019 dan dinyatakan dengan rupiah; (2) Perusahaan Food and Beverage yang tidak melaporkan kerugian selama tahun pengamatan; (3) Perusahaan Food and Beverage yang menyajikan informasi yang berkaitan dengan variabel yang teliti. Variabel independen yang digunakan dalam penelitian ini adalah ukuran perusahaan, ukuran KAP, profitabilitas, solvabilitas dan komite audit. Variabel dependen dalam penelitian ini adalah audit delay.

\section{Metode Analisis}

1. Variabel dependen yaitu variabel yang dipengaruhi oleh variabel lain (Widiyanto, 2013). Variabel dependen dalam penelitian ini adalah Audit Delay yaitu jangka waktu antara tanggal penutupan tahun buku sampai dengan tanggal ditandatanganinya laporan auditor independen. Variabel ini diukur secara kuantitatif dalam jumlah hari.

\section{Audit Delay $=$ Tanggal Laporan Audit - Tanggal Tutup Buku}

2. Ukuran perusahaan dalam penelitian ini adalah total aset perusahaan yang tercantum dalam laporan keuangan perusahaan akhir periode yang telah diaudit, yang dapat diakses melalui www.idx.co.id. Total aset dapat mewakili besarnya suatu perusahaan, sesuai dengan pernyataan dalam SAK 2014 yaitu total aktiva menunjukkan total sumber daya yang dimiliki oleh perusahaan yang akan memberikan manfaat ekonomis di masa yang akan datang. Dalam penelitian ini, ukuran perusahaan diukur meggunakan total aset perusahaan dengan menggunakan $\log$ size (natural logaritma).

\section{Ukuran Perusahaan $=$ Ln $($ Total Asset $)$}

3. Kantor Akuntan Publik (KAP) adalah suatu bentuk organisasi akuntan publik yang memperoleh izin usaha sesuai dengan peraturan perundang-undangan, sebagai wadah bagi akuntan publik dalam memberikan jasa (Apriani \& Rahmanto (2017). Dalam penelitian ini KAP dikategorikan menjadi KAP the big four dan KAP non big four dan menggunakan variabel dummy. Variabel dummy adalah sebuah variabel nominal yang digunakan di dalam regresi linear berganda yang diberi kode 1 dan 0, KAP the big four akan diberi nilai 1 dan KAP non big four diberi nilai 0 .

4. Profitabilitas adalah kemampuan perusahaan untuk memperoleh laba, profitabilitas diukur dengan rasio Return On Assets (ROA) yang hitung berdasarkan laba bersih dibagi dengan total aktiva, perusahaan yang memiliki profitabilitas tinggi diduga waktu yang diperlukan untuk menyelesaikan auditnya akan lebih pendek dibandingkan perusahaan dengan Profitabilitas rendah (Tantama \& Yanti, 2018). Profitabilitas dapat dirumuskan sebagai berikut:

$R O A=\frac{\text { laba bersih setelah pajak }}{\text { total Aset }}$

5. Solvabilitas perusahaan adalah kemampuan suatu perusahaan untuk memenuhi kewajiban finansialnya pada saat perusahaan dilikuidasi, solvabilitas perusahaan dalam penelitian ini diukur menggunakan debt to asset rasio yang dihitung dengan cara membandingkan jumlah utang baik utang jangka panjang mapun jangka pendek dengan jumlah aktiva (total asset) (Tantama \& Yanti, 2018). Solvabilitas dapat dirumuskan sebagai berikut :

$D A R=\frac{\text { Total Liabilities }}{\text { Total Asset }}$

6. Komite Audit merupakan komite yang dibentuk oleh dan bertanggung jawab kepada dewan komisaris dalam membantu melaksanakan tugas dan fungsi dewan komisaris (Siahaan et al., 2019) variabel komite audit dalam penelitian ini diukur dengan menghitung jumlah komite audit pada perusahaan Food And Beverage pada suatu periode. 
Friska Yuliana, Riana Rachmawati Dewi dan Rosa Nikmatul Fajri, Pengaruh Karakteristik Perusahaan Terhadap Lamanya Penyelesaian Audit (Audit Delay) (Studi Empiris pada Perusahaan Food And Beverage yang Terdaftar di Bursa Efek Indonesia Periode 2017-2019)

\section{HASIL DAN PEMBAHASAN}

Tabel 1

Hasil Uji Deskriptif

\begin{tabular}{lcrrrr}
\hline & N & \multicolumn{1}{c}{ Minimum } & Maximum & Mean & Std.devisiasi \\
\hline Audit Delay & 41 & 46,00 & 115,00 & 77,3659 & 11,99532 \\
Ukuran Perusahaan & 41 & 14,74 & 30,50 & 23,2455 & 5,81171 \\
Ukuran KAP & & & & & 0,48765 \\
Profitabilitas & 41 & 0,00 & 1,00 & 0,3659 & 0,11347 \\
Solvabilitas & 41 & 0,00 & 0,53 & 0,1106 & 0,16837 \\
Komite Audit & 41 & 0,05 & 0,64 & 0,3608 & 0,15617 \\
Valid N (listwise) & 41 & 3,00 & 4,00 & 3,0244 & \\
\hline
\end{tabular}

Sumber: data olahan

Berdasarkan tabel $1 \mathrm{di}$ atas dari hasil analisis statistik deskriptif, menjelaskan tentang besarnya nilai minimum, maximum, mean dan st.deviasi dari hasil uji deskriptif dari 39 data penelitian. Dalam tabel tersebut terlihat bahwa Audit Delay memiliki nilai minimum 46,00 nilai maksimum 115,00 untuk mean 77,3659 dan std.deviasinya 11,99532. Untuk variabel Ukuran Perusahaan nilai minimumnya adalah 14,74 dan nilai maksimumnya sebesar 30,50, hasil dari mean 23,2455 dan std.deviasi 5,81171. Hasil variabel Ukuran KAP dengan nilai minimum 0,00 dan nilai maksimum 1,00, untuk mean 0,3659 dan std.deviasi 0,48765. Untuk varibel Profitabilitas memiliki nilai minimum 0,00 dan maksimum 0,53 dengan nilai mean 0,1106 dan std.deviasi 0,11347 . Untuk variabel Solvabilitas memiliki nilai minimum 0,05 dan nilai maksimum 0,64, dengan nilai mean 0,3608 dan standar deviasi 0,16837. Variabel yang terakhir adalah Komite Audit dengan nilai minimum 3,00 dan nilai maksimum 4,00, sedangkan nilai rata-ratanya 3,0244 dengan std.deviasi 0,15617. Uji asumsi klasik dilakukan agar uji regresi linear berganda dalam penelitian ini memiliki hasil yang signifikan dan representatif. Berdasarkan hasil uji asumsi klasik yang telah dilakukan menunjukan bahwa semua model regresi dalam penelitian ini memenuhi asumsi klasik.

Tabel 2

Hasil Uji Regresi Linier Berganda

\begin{tabular}{|c|c|c|}
\hline Variabel & $\beta$ (Koefisien Regresi) & Signifikansi \\
\hline Konstanta & 82,236 & 0,007 \\
\hline Ukuran Perusahaan & $-0,413$ & 0,131 \\
\hline Ukuran KAP & $-5,487$ & 0,067 \\
\hline Profitabilitas & $-55,953$ & 0,000 \\
\hline Solvabilitas & $-34,825$ & 0,000 \\
\hline Komite Audit & 8,432 & 0,355 \\
\hline
\end{tabular}

Sumber: data olahan berikut :

Berdasarkan hasil pengujian pada Tabel 2 dengan menggunakan SPSS, maka didapat persamaan regresi sebagai $Y=82,236-0,413 X_{1}-5,487 X_{2}-55,953 X_{3}-34,825 X_{4}+8,432 X_{5}$

Persamaan regresi yang terbentuk diatas memberikan suatu pengertian sebagai berikut :

1. Kostanta diperoleh nilai positif sebesar 82,236 menyatakan bahwa semua varianel independen (ukuran perusahaan, ukuran KAP, profitabilitas, solvabilitas dan komite audit) bernilai 0, maka audit delay bernilai sebesar $82,236$.

2. Koefisien regresi variabel ukuran perusahaan bernilai negatif sebesar -0,413. Hal ini berarti apabila variabel ukuran perusahaan naik sebesar 1 persen dengan asumsi variabel independen yang lainnya tetap, maka akan diikuti penurunan audit delay sebesar $-0,413$.

3. Koefisien regresi variabel ukuran KAP bernilai negatif sebesar -5,487 Hal ini berarti apabila variabel ukuran KAP naik sebesar 1 persen dengan asumsi variabel independen yang lainnya tetap, maka akan diikuti penurunan audit delay sebesar $-5,487$.

4. Koefisien regresi variabel profitabilitas bernilai negatif sebesar $-55,953$ Hal ini berarti apabila variabel profitabilitas naik sebesar 1 persen dengan asumsi variabel independen yang lainnya tetap, maka akan diikuti penurunan audit delay sebesar $-55,953$.

5. Koefisien regresi variabel solvabilitas bernilai negatif sebesar -34,825 Hal ini berarti apabila variabel solvabilitas naik sebesar 1 persen dengan asumsi variabel independen yang lainnya tetap, maka akan diikuti penurunan audit delay sebesar $-34,825$. 
Friska Yuliana, Riana Rachmawati Dewi dan Rosa Nikmatul Fajri, Pengaruh Karakteristik Perusahaan Terhadap Lamanya Penyelesaian Audit (Audit Delay) (Studi Empiris pada Perusahaan Food And Beverage yang Terdaftar di Bursa Efek Indonesia Periode 2017-2019)

6. Koefisien regresi variabel komite audit bernilai positif sebesar 8,432 Hal ini berarti apabila variabel solvabilitas naik sebesar 1 persen dengan asumsi variabel independen yang lainnya tetap, maka akan diikuti kenaikan audit delay sebesar 8,432 .

Tabel 3

Hasil Uji Kelayakan Modal (Uji F)

\begin{tabular}{ccccc}
\hline $\mathrm{F}_{\text {Hitung }}$ & $\mathrm{F}_{\text {Tabel }}$ & Sig & Syarat & Keterangan \\
\hline 9,170 & 2,641 & $0,000^{\mathrm{b}}$ & $<0,05$ & Model Layak \\
\hline
\end{tabular}

Sumber: data olahan

Berdasarkan hasil kelayakan model (uji F) pada tabel 3 diatas menunjukkan bahwa variabel independen memiliki nilai $F_{\text {hitung }} 9,170$ serta signifikansi sebesar 0,000 dengan df 1 (jumlah variabel) $=(5-1)=4$ dan df $2=41$ $5-1=35$ Maka hasil $F$ tabel yang diperoleh sebesar 2,641, maka Ho ditolak sehingga dapat disimpulkan bahwa terdapat pengaruh yang signifikan antara variabel independen dengan variabel dependen.

Tabel 4

Hasil Uji Hipotesis (Uji t)

\begin{tabular}{lccccc}
\hline \multicolumn{1}{c}{ Hipotesis } & $\mathrm{t}_{\text {hitung }}$ & $\mathrm{t}_{\text {tabel }}$ & $\mathrm{Sig}$ & $\mathrm{Std}$ & \multicolumn{2}{c}{ Kesimpulan } \\
\hline Ukuran Perusahaan & $-1,546$ & $-2,030$ & 0,131 & $>0,05$ & Ditolak \\
Ukuran KAP & $-1,893$ & $-2,030$ & 0,067 & $>0,05$ & Ditolak \\
Profitabilitas & $-4,124$ & $-2,030$ & 0,000 & $<0,05$ & Diterima \\
Solvabilitas & $-4,197$ & $-2,030$ & 0,000 & $<0,05$ & Diterima \\
Komite Audit & 0,938 & 2,030 & 0,355 & $>0,05$ & Ditolak \\
\hline
\end{tabular}

Sumber: data olahan

\section{Hasil Pengujian Hipotesis}

1. Pengaruh Ukuran Perusahaan terhadap Audit Delay

Berdasarkan hasil perhiungan pada tabel 4 diatas diketahui Ukuran Perusahaan memiliki nilai $t_{\text {hitung }}-1,546$. Sedangkan nilai $\mathrm{t}_{\text {tabel }}$ terletak pada angka -2,030. Jadi dapat disimpulkan bahwa $\mathrm{t}_{\text {hitung }}<\mathrm{t}_{\text {tabel }}$ yaitu $-1,546<-2,030$. Nilai signifikansi juga menunjukkan $0,131>0,05$ sebagai standar signifikan. Hal ini berarti variabel ukuran perusahaan tidak berpengaruh terhadap audit delay atau dengan kata lain $\mathrm{H}_{1}$ ditolak.

2. Pengaruh Ukuran KAP terhadap Audit Delay

Berdasarkan hasil perhiungan pada tabel 4 diatas diketahui Ukuran KAP memiliki nilai $t_{\text {hitung }}-1,893$. Sedangkan nilai $t_{\text {tabel }}$ terletak pada angka $-2,030$. Jadi dapat disimpulkan bahwa $t_{\text {hitung }}<t_{\text {tabel }}$ yaitu $-1,893<-2,030$. Nilai signifikansi juga menunjukkan 0,067 > 0,05 sebagai standar signifikan. Hal ini berarti variabel ukuran KAP tidak berpengaruh terhadap audit delay atau dengan kata lain $\mathbf{H}_{\mathbf{2}}$ ditolak.

3. Pengaruh Profitabilitas terhadap Audit Delay

Berdasarkan hasil perhiungan pada tabel 4 diatas diketahui Profitabilitas memiliki nilai $t_{\text {hitung }}-4,124$. Sedangkan nilai $t_{\text {tabel }}$ terletak pada angka -2,030. Jadi dapat disimpulkan bahwa $t_{\text {hitung }}>t_{\text {tabel }}$ yaitu $-4,124>-2,030$. Nilai signifikansi juga menunjukkan $0,000<0,05$ sebagai standar signifikan. Hal ini berarti variabel profitabilitas berpengaruh terhadap audit delay atau dengan kata lain $\mathbf{H}_{\mathbf{3}}$ diterima.

4. Pengaruh Solvabilitas terhadap Audit Delay

Berdasarkan hasil perhiungan pada tabel 4 diatas diketahui Solvabilitas memiliki nilai $t_{\text {hitung }}-4,197$. Sedangkan nilai $t_{\text {tabel }}$ terletak pada angka 2,030. Jadi dapat disimpulkan bahwa $t_{\text {hitung }}>t_{\text {tabel }}$ yaitu $-4,197>-2,030$. Nilai signifikansi juga menunjukkan $0,000<0,05$ sebagai standar signifikan. Hal ini berarti variabel solvabilitas berpengaruh terhadap audit delay atau dengan kata lain $\mathbf{H}_{\mathbf{4}}$ diterima.

5. Pengaruh komite audit terhadap audit delay

Berdasarkan hasil perhiungan pada tabel 4 diatas diketahui Komite Audit memiliki nilai thitung 0,938. Sedangkan nilai $t_{\text {tabel }}$ terletak pada angka 2,030. Jadi dapat disimpulkan bahwa $t_{\text {hitung }}<t_{\text {tabel }}$ yaitu $0,938<2,030$. Nilai signifikansi juga menunjukkan 0,355 > 0,05 sebagai standar signifikan. Hal ini berarti variabel komite audit tidak berpengaruh terhadap audit delay atau dengan kata lain $\mathbf{H}_{\mathbf{5}}$ ditolak.

Tabel 5

Hasil Uji Koefisien Determinan

\begin{tabular}{|c|c|c|}
\hline Model & Adjstuted R Square & Kesimpulan \\
\hline 1 & 0,505 & Variabel independen dapat menjelaskan variabel dependen \\
\hline
\end{tabular}

Sumber: data olahan 
Berdasarkan tabel 5 di atas uji koefisien determinasi $\left(\mathrm{R}^{2}\right)$ pada tabel 5 menunjukkan bahwa variabel independen yang digunakan dalam penelitian ini dapat menjelaskan variasi variabel dependen dalam hal ini adalah audit delay sebesar 50,5\%. Hal ini terlihat dari nilai Adjsuted $R$ Square sebesar 0,505 sedangkan 49,5\% variabel dependen audit delay dipengaruhi oleh variabel-variabel yang lain diluar model penelitian ini.

1. Pengaruh Ukuran Perusahaan terhadap Audit Delay

Berdasarkan hasil pengujian hipotesis pertama menunjukkan bahwa ukuran perusahaan tidak berpengaruh terhadap audit delay. Hal ini dikarenakan ukuran perusahaan yang besar maupun kecil mempunyai tekanan yang sama atas penyampaian laporan keuangan. Selain itu, auditor menganggap bahwa dalam proses pengauditan berapapun jumlah aset yang dimiliki perusahaan akan diperiksa dengan cara yang sama, sesuai dengan prosedur dalam Standar Profesional Akuntan Publik (SPAP). Hasil penelitian ini mendukung penelitian sebelumnya yang dilakukan oleh Liwe et al., (2018), Tantama \& Yanti (2018) menyatakan bahwa ukuran perusahaan tidak mempunyai pengaruh terhadap audit delay, sedangkan hasil penelitian ini bertentangan dengan penelitian oleh Candraningtiyas et al., (2017), Alawiah Magfira (2019) yang menyatakan bahwa ukuran perusahaan berpengaruh terhadap audit delay.

2. Pengaruh Ukuran KAP terhadap Audit Delay

Berdasarkan hasil pengujian hipotesis kedua menunjukkan bahwa ukuran KAP tidak berpengaruh terhadap audit delay. Hal ini dikarenakan semakin baik kualitas KAP maka KAP tersebut belum tentu memberikan jaminan terhadap kualitas audit yang dilakukan salah satunya ketepatan waktu dalam menyampaikan laporan audit, dimana seharusnya semakin besar KAP, sumber daya yang dimiliki semakin banyak, lebih banyak auditor ahli, dan memiliki sistem kerja audit yang baik sehingga akan akan mempercepat dalam penyelesian audit atas laporan keuangan, selain itu kualitas KAP yang baik juga akan lebih tepat waktu dalam menyampaikan laporan audit untuk menjaga image atau citra KAP dimata publik. Hasil penelitian ini mendukung penelitian sebelumnya yang dilakukan oleh Apriani \& Rahmanto (2017), Manalu \& Majidah (2018) menyatakan bahwa ukuran KAP tidak mempunyai pengaruh terhadap audit delay, sedangkan hasil penelitian ini bertentangan dengan penelitian yang dilakukan oleh Candraningtiyas et al., (2017), Harjanto (2018) yang menyatakan bahwa ukuran KAP berpengaruh terhadap audit delay.

3. Pengaruh Profitabilitas terhadap Audit Delay

Berdasarkan hasil pengujian hipotesis ketiga menunjukkan bahwa profitabilitas berpengaruh terhadap audit delay. Hal ini dikarenakan semakin besar kemampuan perusahaan untuk menghasilkan laba, maka transaksi penjualan yang ada dalam perusahaan tersebut akan semakin banyak. Dengan adanya laba yang besar, maka akan ada tuntutan dari pihak manajemen untuk mempercepat memberikan kabar baik kepada publik. Tapi disisi lain, auditor akan semakin berhati-hati dalam melihat setiap detail penjualan yang ada, apakah penjualan itu benar-benar terjadi atau hanya penjualan fiktif supaya perusahaan bisa menghasilkan laba, karena kehati-hatian itulah yang membuat laporan audit akan lama selesai. Hasil penelitian ini mendukung penelitian sebelumnya yang dilakukan oleh Candraningtiyas et al., (2017), Liwe et al., (2018), menyatakan bahwa profitabilitas mempunyai pengaruh terhadap audit delay, sedangkan hasil penelitian ini bertentangan dengan penelitian yang dilakukan oleh Effenadi (2018), Alawiah Magfira (2019), yang menyatakan bahwa profitabilitas tidak berpengaruh terhadap audit delay.

4. Pengaruh Solvabilitas terhadap Audit Delay

Berdasarkan hasil pengujian hipotesis keempat menunjukkan bahwa solvabilitas berpengaruh terhadap audit delay. Hal ini dikarenakan DAR merupakan salah satu indikator yang dapat mengukur kemampuan perusahaan dalam memenuhi kewajibannya baik jangka panjang maupun jangka pendek. Perusahaan dengan DAR yang tinggi akan memunculkan kesan bad news dari pihak kreditur, hal tersebut dikarenakan mempunyai resiko kebangkrutan yang lebih tinggi. Dalam pengukuran ini juga menyatakan bahwa total aset yang dimiliki perusahaan sebagian dibiayai oleh hutang oleh sebab itu perusahaan yang memiliki DAR tinggi akan memperpanjang audit delay. Hasil penelitian ini mendukung penelitian sebelumnya yang dilakukan oleh Candraningtiyas et al. (2017), Tantama \& Yanti, (2018) menyatakan bahwa solvabilitas mempunyai pengaruh terhadap audit delay, sedangkan hasil penelitian ini bertentangan dengan penelitian yang dilakukan oleh Liwe et al., (2018), Siahaan et al., (2019) yang menyatakan bahwa solvabilitas tidak berpengaruh terhadap audit delay.

5. Pengaruh komite audit terhadap audit delay

Berdasarkan hasil pengujian hipotesis kelima menunjukkan bahwa komite audit tidak berpengaruh terhadap audit delay. Hal ini dikarenakan komite audit tidak berperan secara langsung dalam penyusunan laporan audit, karena tugas utama komite audit yaitu hanyalah bertugas sebagai pengawas independen sehingga wewenang dalam penerbitan laporan audit suatu perusahaan masih sebagian besar ditetapkan oleh auditor sebagai pengaudit laporan keuangan, sehingga panjang atau pendeknya penerbitan laporan audit suatu perusahaan tidak berpengaruh terhadap audit delay pada suatu perusahaan. Hasil penelitian ini mendukung penelitian sebelumnya yang dilakukan oleh Purnami et al., (2019), Siahaan et al., (2019) yang menyatakan bahwa komite audit tidak mempunyai pengaruh 
Friska Yuliana, Riana Rachmawati Dewi dan Rosa Nikmatul Fajri, Pengaruh Karakteristik Perusahaan Terhadap Lamanya Penyelesaian Audit (Audit Delay) (Studi Empiris pada Perusahaan Food And Beverage yang Terdaftar di Bursa Efek Indonesia Periode 2017-2019)

terhadap audit delay, sedangkan hasil penelitian ini bertentangan dengan penelitian oleh Eksandy (2017) yang menyatakan bahwa komite audit berpengaruh terhadap audit delay.

\section{SIMPULAN}

Penelitian ini dimaksudkan untuk menguji secara empiris pengaruh dari ukuran perusahaan, ukuran kantor akuntan publik (KAP), profitabilitas, solvabilitas dan komite audit terhadap audit delay. Populasi pada penelitian ini adalah 63 perusahaan, setelah menggunakan metode purposive sampling didapat sebanyak 15 sampel perusahaan yang memenuhi kriteria, perusahaan tersebut tergabung dalam perusahaan manufaktur food and beverage dalam kurun waktu 3 tahun yaitu 2017-2019. Teknik analisis data yang digunakan dalam penelitian ini adalah uji deskriptif, uji asumsi klasik (Uji Normalitas, uji mutikoloniaritas, uji autokorelasi dan uji heteroskedastisitas), dan uji regresi linier berganda. Berdasarkan hasil temuan penelitian dan pengujian hipotesis yang telah dilakukan maka dapat disimpulkan bahwa ukuran perusahaan, ukuran kantor akuntan publik (KAP) dan komite audit tidak berpengaruh terhadap audit delay, sedangkan profitabilitas dan solvabilitas berpengaruh terhadap audit delay.

\section{DAFTAR PUSTAKA}

Alawiah Magfira, H. D. H. (2019). PENGARUH UKURAN PERUSAHAAN, SOLVABILITAS, DAN PROFITABILITAS TERHADAP AUDIT DELAY Studi Empiris Pada Perusahaan Sektor Perbankan Yang Terdaftar Di Bursa Efek Indonesia.

Apriani, S., \& Rahmanto, B. T. (2017). Analisis Pengaruh Profitabilitas, Ukuran Perusahaan Dan Ukuran Kantor Akuntan Publik (Kap) Terhadap Audit Delay Pada Perusahaan Pertambangan Periode 2010 - 2014. Jurnal Riset Manajemen Dan Bisnis (JRMB) Fakultas Ekonomi UNIAT, 2(September), 261-270.

Apriyana, N. (2017). Pengaruh Profitabilitas, Solvabilitas, Ukuran Perusahaan, Dan Ukuran Kap Terhadap Audit Delay Pada Perusahaan Properti Dan Real Estate Yang Terdaftar Di Bursa Efek Indonesia Periode 2013-2015. Jurnal Nominal, VI(3).

Candraningtiyas, E. G., \& Luh. (2017). Pengaruh Ukuran Perusahaan, Profitabilitas, Solvabilitas, Dan Ukuran Kantor Akuntan Publik Terhadap Audit Delay Pada Perusahaan Perbankan Yang Terdaftar Di Bei Tahun 2012-2015. Jurusan Akuntansi, l(1).

Candraningtiyas, E. G., Sulindawati, N. L. G. E., \& Wahyuni, M. A. (2017). Pengaruh Ukuran Perusahaan, Profitabilitas, Solvabilitas, Dan Ukuran Kantor Akuntan Publik Terhadap Audit Delay Pada Perusahaan Perbankan Yang Terdaftar Di Bei Tahun 2012-2015. E-Journal S1 Ak Universitas Pendidikan Ganesha, 8(2), 111.

Effendi, B. (2018). Profitabilitas, Solvabilitas Dan Audit Delay Pada Perusahaan Consumer Goods Yang Terdaftar Di BEI. Riset \& Jurnal Akuntansi, 2(2), 100-108, ISSN: 2548-9224.

Eksandy, A. (2017). Pengaruh Ukuran Perushaan, Solvabilitas, Profitabilitas Dan Komite Audit Terhadap Audit Delay (Pada Perusahaan Properti dan Real Estate yang Terdaftar di Bursa Efek Indonesia Pada Tahun 2012-2015). Вестник Росздравнадзора, 6(2), 5-9.

Firliana, I. (2015). Pengaruh Ukuran Perusahaan, Profitabilitas, Dan Solvablitas Terhadap Audit Delay ( Studi Pada Perusahaan LQ 45 Sub-Sektor Bank serta Manufaktur yang Terdaftar di Bursa Efek Indonesia ( BEI) Tahun $2011 \pm 2015$ ). 46(1), 2011-2018.

Harjanto, K. (2018). Pengaruh Ukuran Perusahaan, Profitabilitas, Solvabilitas, dan Ukuran Kantor Akuntan Publik terhadap Audit Delay. Jurnal ULTIMA Accounting, 9(2), 33-49.

Hidayat, V. S. (2017). Pengaruh Profitabilitas, Solvabilitas, dan Aktivitas Persediaan terhadap Audit Delay pada Perusahaan Retail yang terdaftar di Bursa Efek Indonesia Periode 2014-2015 Debbianita. 9(November), 158169.

Liwe, A. G., Manossoh, H., \& Mawikere, L. M. (2018). Analisis Faktor-Faktor Yang Mempengaruhi Audit Delay (Studi Empiris Pada Perusahaan Property Dan Real Estate Yang Terdaftar Di Bursa Efek Indonesia). In Going Concern : Jurnal Riset Akuntansi (Vol. 13).

Manalu, D. A., \& Majidah. (2018). Analisis Yang Mempengaruhi Audit Delay (Studi Empiris pada Perusahaan Sektor Pertambangan yang Terdaftar di Bursa Efek Indonesia Periode 2012-2016). E-Proceeding of Management, 5(3), 2061-2068.

Mubarok, A. (2016). Faktor - Faktor Yang Mempengaruhi Audit Delay Dan Relevansinya Terhadap Timeliness. Jurnal Unpam, 1(2), 1-26.

Pangerapan, S. (2019). Pengaruh Ukuran Perusahaan, Solvabilitas, Profitabilitas, Dan Ukuran Kap Terhadap Audit Delay Pada Perusahaan Sektor Pertambangan Yang Terdaftar Di Bursa Efek Indonesia. Jurnal EMBA, 7(3), 3069-3078.

Purnami, N. K. Y., Kurniawan, P. S., \& Wahyuni, M. A. (2019). Pengaruh Jenis Industri, Laba Dan Rugi Operasi, 
Friska Yuliana, Riana Rachmawati Dewi dan Rosa Nikmatul Fajri, Pengaruh Karakteristik Perusahaan Terhadap Lamanya Penyelesaian Audit (Audit Delay) (Studi Empiris pada Perusahaan Food And Beverage yang Terdaftar di Bursa Efek Indonesia Periode 2017-2019)

Dewan Komisaris Dan Komite Audit Terhadap Kecenderungan Audit Delay (Study Empiris Pada Perusahaan Lq-45 Bursa Efek Indonesia Tahun 2015-2017). JIMAT (Jurnal Ilmiah Mahasiswa Akuntansi) Universitas Pendidikan Ganesha, 10(1), 49-60.

Rosalia, N., Sukesti, F., \& Wibowo, R. E. (2018). Pengaruh Profitabilitas, Ukuran Perusahaan, Opini Audit dan Ukuran KAP Terhadap Audit Delay (Studi Pada Perusahaan Property dan Real Estate Yang Terdaftar Di Bursa Efek Indonesia 2014-2017). Prosiding Seminar Nasional Mahasiswa Unimus, 1, 412-417.

Sari, D. P. (2018). Faktor - Faktor Yang Mempengaruhi Audit Delay (Studi Empiris Pada Perusahaan Pertambangan Yang Terdaftar di Bursa Efek Indonesia Tahun 2014-2017). Jurnal Eksplorasi Akuntansi, 13(A), 99-108.

Siahaan, I., Surya, R. A. S., \& Zarefar, A. (2019). Pengaruh Opini Audit, Pergantian Auditor, Kesulitan Keuangan, dan Efektivitas Komite Audit Terhadap Audit Delay (Studi Empiris Pada Seluruh Perusahaan Yang Terdaftar Di Bursa Efek Indonesia Tahun 2014- 2017). Jurnal Akuntansi Keuangan Dan Bisnis, 12(2), 135-144.

Simatupang Laurencius, Putra Wirmie Eka, H. N. (2018). Jurnal ilmiah wahana akuntansi. Jurnal Ilmiah Wahana Akuntansi, 13(2), 95-109.

Tantama, H., \& Yanti, L. D. (2018). Pengaruh Audit Tenure, Profitabilitas, Solvabilitas Dan Ukuran Perusahaan Terhadap Audit Delay (Studi Empiris Pada Perusahaan Manufaktur Pada Sub Sektor Makanan Dan Minuman Yang Terdaftar Di Bursa Efek Indonesia Pada Tahun 2014-2017). Akuntoteknologi, 10(1), 1-15.

Vicky Anggel Putra. (2017). Pengaruh Ukuran Perusahaan, Ukuran Kap, Solvabilitas, Auditor Switching, Dan Opini Audit Terhadap Audit Delay. Artikel Ilmiah.

Widiyanto, M.A (2013). Statistika Terapan, Jakarta : PT Elex Media Komputindo. 